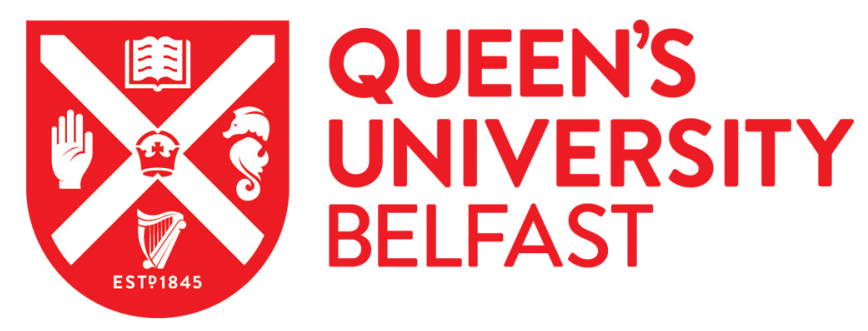

\title{
Prejudice in the wake of terrorism: The role of temporal distance, ideology, and intergroup emotions
}

Choma, B. L., Jagayat, A., Hodson, G., \& Turner, R. (2018). Prejudice in the wake of terrorism: The role of temporal distance, ideology, and intergroup emotions. Personality and Individual Differences, 123, 65-75. https://doi.org/10.1016/j.paid.2017.11.002

Published in:

Personality and Individual Differences

Document Version:

Peer reviewed version

Queen's University Belfast - Research Portal:

Link to publication record in Queen's University Belfast Research Portal

Publisher rights

(C) 2017 Elsevier Ltd. All rights reserved.

This manuscript version is made available under the CC-BY-NC-ND 4.0 license http://creativecommons.org/licenses/by-nc-nd/4.0/,which permits distribution and reproduction for noncommercial purposes, provided the author and source are cited.

\section{General rights}

Copyright for the publications made accessible via the Queen's University Belfast Research Portal is retained by the author(s) and / or other copyright owners and it is a condition of accessing these publications that users recognise and abide by the legal requirements associated with these rights.

Take down policy

The Research Portal is Queen's institutional repository that provides access to Queen's research output. Every effort has been made to ensure that content in the Research Portal does not infringe any person's rights, or applicable UK laws. If you discover content in the Research Portal that you believe breaches copyright or violates any law, please contact openaccess@qub.ac.uk. 
Islamoprejudice 1

Prejudice in the wake of terrorism:

The role of temporal distance, ideology, and intergroup emotions

Rebecca L. Choma

Arvat Jagayat

Gordon Hodson

Rhiannon N. Turner 
Islamoprejudice 2

\begin{abstract}
The shootings at the Canadian Parliament on October 22, 2014 received international coverage and fueled concerns about terrorism and growing Islamoprejudice. In the wake of this event, our two studies ( $n=215, n=492)$ investigated objective temporal distance, right-wing ideology, and intergroup emotions as predictors of prejudice, outgroup trust, and the restriction of civil liberties. Objective temporal distance from the shootings was also examined as a moderator of the relations between ideology and intergroup emotions with intergroup attitudes. Results showed that greater endorsement of right-wing ideologies, higher intergroup anxiety, or higher intergroup disgust were associated with greater prejudice and lower outgroup trust. Of particular note, participants who completed the survey further from (vs. closer to) the event reported more positive intergroup attitudes and were less likely to endorse restricting civil liberties. Objective temporal distance also moderated some of the associations between intergroup emotions with intergroup attitudes. Implications are discussed.
\end{abstract}


Islamoprejudice 3

Public opinion polls demonstrate that terrorist activities carried out by individuals identifying as Muslim are followed by anti-Islam and anti-Muslim surges. For example, following an $81 \%$ surge of fatalities from terrorist attacks worldwide in 2014 compared to 2013 (Strobel, June 19, 2015), and a string of widely reported terrorist attacks in 2015, including the Charlie Hebdo shootings and the November 2015 Paris attacks, anti-Muslim assaults in the United States rose 69\% in 2015 (Federal Bureau of Investigation, 2015), reaching levels just shy of those post-9/11. Studies comparing levels of prejudice before and after attacks similarly show that terrorist events foster greater prejudice (Van de Vyver, Houston, Abrams, \& Vasiljevic, 2016). Terrorist attacks often also correspond with less opposition to government surveillance and the restriction of civil liberties (Davis \& Silver, 2004; Hodson, Esses, \& Dovidio, 2006; Huddy \& Feldman, 2011; Morgan, Wisneski, \& Skitka, 2011; Vasilopoulos, Marcus, \& Foucault, 2017; Whitehead \& Aden, 2000). Similar effects are also noted for perceived threat of terrorist attacks (Doosje, Zimmermann, Küpper, Zick, \& Meertens, 2009; Huddy, Feldman, Taber, \& Lahav, 2005; Oswald, 2005; Skitka, Bauman, \& Mullen, 2004) or when viewing footage of attacks (Choma, Charlesford, Dalling, \& Smith, 2015).

Of relevance to the present research, on October 22, 2014, a gunman shot and killed Cpt. Nathan Cirillo, who was ceremonially guarding the National War Memorial in Ottawa, Canada. The shooter then entered the Canadian Parliament, and after exchanging gunfire, was shot dead. Prior to the attack, the assailant recorded a video explaining that he was "retaliating" against Canada's military involvement in Afghanistan and the proposal by then Prime Minister Stephen Harper for Canada to deploy fighter jets to Iraq. He believed Canada should "stop occupying and killing the righteous of us who are trying to bring back religious laws in our countries" (CBC, 2015). Canadian authorities confirmed that, despite the mental health issues plaguing him, he 
would have been charged with terrorism (Bronskill, 2016). Much of the news focused more heavily on his mental health as a contributing factor, but the fact that he had converted to Islam was noted. The implications for Muslim and Islam-sentiment were particularly salient as the event occurred only two days after another terrorist attack where a man, inspired by the Islamic State of Iraq and the Levant (ISIL), struck two Canadian soldiers with a car, killing one of them (CBC, October 20, 2014).

To our knowledge, this is the first study to investigate objective temporal distance (from the shootings) alongside ideology and intergroup emotions. These variables were examined as predictors of prejudice toward Muslims, Islamophobia, intergroup trust of Muslims, and attitudes toward the restriction of civil liberties in the days and months following the shooting at the Canadian Parliament; a time when discussions of Muslims and terrorism were particularly salient for Canadians. We also considered objective temporal distance from the shootings as a potential moderator of the relations between ideology and intergroup emotions with intergroup attitudes. We were particularly interested in whether attitudes were more positive when participants reported their opinions at a time further from (vs. closer to) the event, and whether relations between ideology and intergroup emotions with intergroup attitudes were weaker when reported further (vs. closer) from the event.

\section{Temporal Distance}

It is well documented that terrorism and collective tragedies negatively impact personal wellbeing (Norris, Friedman, \& Watson; Slone, 2000; Stein et al., 2004). Noteworthy is that some research also shows that the personal consequences of terrorism for wellbeing lessen with time (e.g. Stein et al., 2004). A possible lessening trend has not been discussed at length with respect to intergroup attitudes. Fischer and colleagues (2007) propose that terror salience might 
be useful in understanding personal and social consequences of terrorism (see also Fischer et al., 2006), with the salience of terrorism following terror events heightening threats to social order. According to Tetlock (2002), people are more punitive when threats to social order are present versus absent. Testing this prediction in the context of terrorism, Fischer et al. (2007) found that German participants who read about a man who stole a car recommended harsher punishment when they completed the study the day after the London July 7, 2005 bombings (i.e. temporally close to the event) than if they completed the study four weeks after the event (i.e. temporally further from the event). Fischer et al. examined the effects of the bombings on a non-terror related outcome. Research documenting heightened prejudice toward Muslims and preferences for authoritarian policies in the wake of terror events (e.g. FBI, 2015; Davis \& Silver, 2004; Huddy \& Feldman, 2011; Morgan et al., 2011; Vasilopoulos et al., 2017) is consistent with the notion that terror-related threat effects are most salient closer to (vs. further from) a terror event. In this body of research, temporal distance is represented by objective time.

In a related literature, psychological or subjective temporal distance (i.e. perceptions of how close or far away an event feels; e.g. Liberman \& Trope, 1998; Ross \& Wilson, 2002) has also been implicated in reactions to terror events (e.g. Magee, Milliken, \& Lurie, 2010). For example, Van Boven, Kane, McGraw, and Dale (2010) found that participants who were asked to describe the 2007 shootings at Virginia Tech in emotional (vs. neutral) terms were more likely to perceive the shooting as psychologically closer. Thus, temporal distance, real or perceived, is relevant for appreciating peoples' reactions to terror and tragic effects. Drawing on these literatures, we proposed that being closer to (vs. further from) terror events, in terms of objective temporal distance, will also have intergroup implications. 
Islamoprejudice 6

\section{Individual Differences in Ideological Beliefs}

To gauge the possible significance of temporal distance from terror events for intergroup outcomes, we investigated objective temporal distance alongside robust predictors of intergroup and public policy attitudes: namely, ideology and intergroup emotions. The link between authoritarian ideology and intergroup prejudice is well documented (Altemeyer, 1998; for a meta-analysis, see Sibley \& Duckitt, 2008), with longitudinal research indicating a causal role of ideology (Asbrock, Sibley, \& Duckitt, 2010; Duriez, Vansteenkiste, Soenens, \& De Witte, 2007; Kteily, Sidanius, \& Levin, 2011; Sibley, Wilson, \& Duckitt, 2007). Two of the most common indices of authoritarian ideology are right-wing authoritarianism (RWA; Altemeyer, 1981, 1998) and social dominance orientation (SDO; Pratto, Sidanius, Stallworth, \& Malle, 1994; Sidanius \& Pratto, 1999; Sidanius et al., 2017). Individuals who more strongly (vs. weakly) endorse RWA strictly observe traditional social conventions, uncritically acquiesce to legitimate authorities, and support authoritarian aggression (Altemeyer, 1998). Individuals higher (vs. lower) in SDO prefer and support hierarchically structured intergroup relationships over egalitarian ones (Sidanius, Levin, Federico, \& Pratto, 2001; Sidanius et al., 2017).

According to the Dual Process Model of Prejudice and Ideology (Duckitt, 2001; Duckitt \& Sibley, 2017), RWA and SDO predict both unique and shared prejudices. Both RWA and SDO predict prejudice toward dissident groups (e.g. feminists) as these groups present a social threat as well as a challenge to the existing hierarchy (Asbrock et al., 2010; Cantal et al., 2015; Duckitt, 2006; Duckitt \& Sibley, 2007). Both are likely to underlie Muslim/Islam prejudice as Muslims might be perceived as dangerous, lower status, and dissenting. Several studies have documented a link between right-wing ideology and Muslim/Islam prejudice. Using the Islamophobia scale (Lee, Gibbons, Thompson, \& Timani, 2009) that taps fear of Muslims and 
Islam specifically, Lee and colleagues (2013) found that RWA related to affective-behavioural and cognitive subdomains of Islamophobia ( $r=.36, r=.31$, respectively). Similarly, Uenal (2016) reported that greater SDO related to greater anti-Muslim and anti-Islam prejudice in a sample of German participants ( $r \mathrm{~s}=.39, .41$, respectively). Hodson and colleagues (2013) found SDO to predict anti-Muslim prejudice after controlling for intergroup disgust, RWA, need for structure, and political conservatism. Imoff and Recker (2012) found that RWA $(r=.62)$ and SDO $(r=.49)$ correlated with 'Islamoprejudice' (i.e. prejudicial views of Islam). Hence, there is evidence that authoritarian beliefs are associated with negative opinions of Muslims and Islam.

Researchers have also found that RWA and SDO relate to perceiving Muslims as threatening (Kauff, Asbrock, Issmer, Thorner, \& Wagner, 2015; Uenal, 2016). Matthews and Levin (2012) showed that RWA and SDO related to perceiving Muslims as a value threat and an economic threat, and to feeling anger and disgust toward Muslims. Others have also observed implications for discrimination: Kauff and colleagues (2015) reported that people higher on RWA indicated they would be less willing to send their children to school with a teacher wearing a headscarf or move to a district where many Muslims lived. Therefore, the robust connection between right-wing ideology and prejudice seems to extend to prejudice towards Muslims and Islam.

\section{Intergroup Emotions}

In addition to ideology, emotions are strong predictors of intergroup prejudice (Cottrell \& Neuberg, 2005; Fiske, Cuddy, Glick, \& Xu, 2002; Mackie \& Smith, 2002). Arguably, the most commonly studied intergroup emotion is intergroup anxiety, or the experience of uneasiness and discomfort around actual or expected interactions with outgroups (Stephan \& Stephan, 2000). Intergroup anxiety can be "chronic" or "episodic" (i.e. dispositional or situational; Paolini, 
Hewstone, Voci, Harwood, \& Cairns, 2006; Stephan, 2014). According to Stephan (2014), intergroup anxiety consists of three facets: affective (i.e. feeling apprehensive, distressed or uneasy), cognitive (i.e. appraising an expected or actual intergroup interaction as negative), and physiological (i.e. raised blood pressure, skin response, cortisol levels, etc.). The intergroup anxiety scale assesses intergroup anxiety toward specific groups or anxiety about interacting with outgroups, generally, and reflects individual differences in intergroup anxiety (Stephan \& Stephan, 1985). Intergroup anxiety has consistently been associated with negative evaluations of outgroups (see e.g. Pettigrew \& Tropp, 2008; Riek, Mania, \& Gaertner, 2006).

Much of the research investigating whether intergroup anxiety relates to anti-Muslim attitudes has been conducted in the context of intergroup contact, with intergroup anxiety mediating the effect of contact on prejudice (Hutchison \& Rosenthal, 2011; Islam \& Hewstone, 1993; Tausch, Hewstone, \& Roy, 2009; Techakesari, Barlow, Hornsey, \& Sung, 2015; White \& Abu-Rayya, 2012). Most recently, Vedder, Wenink, and van Geel (2017) found that lower intergroup anxiety explained the relation between positive contact with Muslims and more positive attitudes of Muslims. Other research has examined the unique predictive ability of intergroup anxiety. For example, White, Duck, and Newcombe (2012) examined the unique predictive ability of intergroup anxiety when entered with the other intergroup theory threats; intergroup anxiety emerged as the strongest predictor of lower tolerance of Muslims. Similarly, in three samples of Canadian undergraduates, Hodson et al. (2013) reported that greater intergroup anxiety uniquely predicted lower ratings of Muslims on a feeling thermometer when entered with intergroup disgust sensitivity. Thus, research shows that the significance of intergroup anxiety for understanding prejudice extends to prejudice toward Muslims. 
Recently, Hodson and colleagues (Choma, Hodson, \& Costello, 2012; Hodson et al., 2013) introduced the concept of intergroup disgust sensitivity (ITG-DS): an "affect-laden revulsion toward social outgroups, incorporating beliefs in stigma transfer and social superiority" (Hodson et al., 2013, p. 195). Their concept draws on evolutionary (Cottrell \& Neuberg, 2005; Schaller \& Park, 2011) and abstract-ideational perspectives (Rozin, Haidt, \& McCauley, 2008). As an individual difference, ITG-DS captures the tendency to experience disgust and revulsion reactions toward outgroups. Individuals dispositionally higher (vs. lower) in ITG-DS are more prejudiced toward a variety of groups such as Jews, gays/lesbians, ethnic minorities, Blacks (Hodson et al., 2013) and the homeless (Hodson, Dube, \& Choma, 2015). Hence, growing research identifies ITG-DS as a likely significant source of intergroup prejudice.

Of particular relevance to the present research, ITG-DS relates to less favourable attitudes of Muslims (Choma et al., 2012; Hodson et al., 2013) and greater Islamophobia, as measured by Lee et al.’s (2009) Islamophobia scale (Choma, Haji, Hodson, \& Hoffarth, 2016, Samples 1-3). Dispositional and manipulated incidental affect (fear, sadness, happiness, neutral) have been shown to affect the relation between ITG-DS and evaluations of Muslims (Choma et al., 2012). Specifically, the link between ITG-DS and negative evaluations of Muslims is stronger among those who dispositionally experience greater fear and sadness (Study 1) and among those in a fear-inducing (vs. neutral) experimental condition (Study 2). Particularly compelling is that ITG-DS outperforms religious identification in predicting Islamophobia (Choma et al., 2016), and either uniquely or out-predicts attitudes toward Muslims alongside intergroup anxiety, and alongside RWA and SDO (Hodson et al., 2013, Samples 1, 4, and 5). Thus, similar to more widely studied constructs like RWA, SDO, and intergroup anxiety, intergroup disgust sensitivity also informs anti-Muslim and anti-Islamic sentiment. 


\section{Intergroup Trust}

A key factor in promoting harmonious intergroup relationships is intergroup trust (Dovidio, Gaertner, Kawakami, \& Hodson, 2002; Kenworthy et al., 2016; Stephan \& Renfro, 2002; Riek et al., 2006). Intergroup trust can be defined as a sureness that an outgroup has positive intentions and behaves benevolently (Lewicki, McAllister, \& Bies, 1998; Tropp, 2008; Turner, West, \& Christine, 2013). Intergroup trust explains, in part, why positive intergroup contact facilitates positive behavioural intentions toward outgroups (Tam, Hewstone, Kenworthy, \& Cairns, 2009; see also Kenworthy et al., 2016). A similar pattern emerges for imagined contact (Turner et al., 2013). Vezzali, Capozza, Stathi, and Giovannini (2012), for example, showed that imagining interacting with an outgroup member led to more positive behavioural intentions and less dehumanization because of increased intergroup trust. It is evident that positive intergroup contact (including imagined contact) can lead to trust of outgroups (e.g. Cehajic, Brown, \& Castano, 2008; Hewstone, Cairns, Voci, Hamberger, \& Niens, 2006; Tausch, Hewstone, Schmid, Hughes, \& Cairns, 2011; Turner, Hewstone, \& Voci, 2007; see Hodson, Hewstone, \& Swart, 2013 Table 11.2; Miles \& Crisp, 2014); however, little is known about how ideology and intergroup emotions relate to intergroup trust. In two exceptions, Dhont and Van Hiel (2011) found individuals higher in RWA reported less intergroup trust, and Hodson and colleagues (2015) found a negative relation between ITG-DS and intergroup trust. The present research seeks to extend this area of research.

\section{The Present Study}

The present research contributes to existing literature in several ways. First, while there is research supporting several of the proposed associations (e.g. between right-wing ideology and prejudice), this is the first study to simultaneously consider ideology and intergroup emotions as 
predictors of key intergroup variables like intergroup trust and Islamoprejudice. Further, this is the first study to investigate objective temporal distance from a terror event alongside key individual difference predictors of ideology and intergroup emotions. Specifically, we tested whether being closer (vs. further) from the shooting, greater right-wing ideology, and greater intergroup anxiety and intergroup disgust uniquely related to anti-Muslim attitudes, lower outgroup trust of Muslims, Islamophobia (Study 2), and stronger endorsement of restricting civil liberties (Study 2). We also for the first time explored the possibility that objective temporal distance might moderate the relations between ideology and intergroup emotions with the outcome variables, such that the relations would be stronger among those who completed the measures closer to (vs. further from) the terror event. Our data collection occurred in the days and months following the shootings on Parliament Hill in Canada; this provided a unique opportunity to test our predictions in the wake of a real-world terrorist event.

\section{Study 1}

As an initial test of study hypotheses, the relations between objective temporal distance, ideology, and intergroup anxiety with attitudes towards Muslims and intergroup trust of Muslims were examined.

\section{Method}

Participants and procedure. Undergraduate students $\left(n=215 ; M_{\mathrm{age}}=20.58 ; S D=4.60\right.$; 81.9\% female; $49.8 \%$ White, Chinese 8.8\%, Black 6.5\%, Southeast Asian 6.5\%, Filipino 5.1\%, Indian 3.7\%, West Asian/Middle Eastern 3.7\%, Other Asian 1.9\%, Japanese 0.9\%, Pakistani 0.5\%, Other 12.6\%; 30.5\% Catholic, Agnostic 22.1\%, Atheist 11.7\%, Protestant 8.9\%, Hindu 4.2\%, Buddhist 3.8\%, Jewish 3.3\%, Sikh 2.8\%, Baptist 1.4\%, Anglican 0.5\%, United 0.5\%, Other 10.3\%) from Ontario, Canada, completed an online survey for course credit. After providing consent, participants completed measures of ideology, intergroup anxiety, intergroup 
trust, and attitudes towards Muslims. The date participants completed the survey was recorded to provide an objective indication of temporal distance from the shooting. Participants then read a debriefing form. (Participants also completed other measures including personality as part of a larger study that was underway when the event occurred. The shootings at the Canadian Parliament was not mentioned in the study).

\section{Measures.}

Objective temporal distance. Objective temporal distance was determined by counting the number of days between the shootings (October 22, 2014), and the time the participant completed the survey, information which was recorded electronically. Temporal distance ranged from 141 days to 167 days after the event. ${ }^{1}$

Ideology. A 12-item version of the RWA scale (Altemeyer, 1996) was administered to participants. Participants indicated their responses to items (e.g. "Our country will be destroyed someday if we do not smash the perversions eating away at our moral and traditional beliefs") using a scale from 1 (strongly disagree) to 7 (strongly agree). Higher average scores indicated greater RWA $(\alpha=.85)$. Participants also responded to the 16 -item version of the SDO scale (Pratto et al., 1994), indicating the degree to which they agreed or disagreed with statements such as "Some groups of people are just more worthy than others". Participants responded on a scale from 1 (do not agree at all) to 7 (strongly agree). Higher average scores indicated greater SDO $(\alpha=.91)$

Intergroup anxiety (ITG-ANX). Participants were asked to imagine if they were the only member of their social group interacting with a group of Muslims, and subsequently completed

\footnotetext{
${ }^{1}$ The range of days were tied to the months that the psychology undergraduate participant pool was running. The pool did not begin until three weeks into the winter term.
} 
the intergroup anxiety scale (Stephan \& Stephan, 1985), indicating how much they would feel 10 emotions (e.g. awkward) while interacting with them relative to interacting with members of their own social group on a scale from 1 (not at all) to 7 (extremely). Higher average scores indicated greater intergroup anxiety when interacting with Muslims $(\alpha=.91)$.

Intergroup Trust (ITG-TRUST). The 10-item intergroup trust scale (Turner, Hewstone, \& Voci, 2007) was completed by participants. Participants indicated how much they endorsed each statement (e.g. "I can trust Muslim people with personal information about myself") on a scale from 1 (strongly disagree) to 7 (strongly agree). Higher average scores on the first four items indicated greater intergroup trust between the participant and Muslims $(\alpha=.91)$.

Attitudes toward Muslims. Participants responded to eight items (Wright, Aron, McLaughlin-Volpe, \& Ropp, 1997). Participants first indicated their feelings about Muslims on a 1-7 scale with opposing pairs of adjectives (warm-cold, positive-negative, friendly-hostile, suspicious-trusting, respect-contempt, admiration-disgust). Participants then indicated how frequently they felt sympathy and admiration for Muslims on a scale from 1 (never) to 7 (often). Higher average scores across all items indicated generally positive feelings towards Muslims ( $\alpha$ $=.89)$.

\section{Results}

Three univariate outliers (i.e. 3.3SD greater than the mean) were noted and the temporal distance variable was slightly negatively skewed. Therefore, bootstrapping was performed using 1000 samples (see Field, 2013). Means, standard deviations and correlations among study variables are reported in Table 1. Being further away from the terrorist event was associated with greater intergroup trust. Further, greater RWA and SDO were associated with less intergroup 
trust and less favourable Muslim attitudes. Intergroup anxiety related to lower intergroup trust and less favourable attitudes.

Regression analyses. Two hierarchical regression analyses were conducted with intergroup trust or attitudes towards Muslims as the criterion variables. Standardized objective temporal distance, RWA, SDO, and intergroup anxiety were entered in Step 1 and interaction terms were entered in Step 2. Bootstrapping was used, and simple slopes analyses probed significant interactions. Regression results are shown in Table 2.

Intergroup trust. In Step 1, as predicted, responding closer to the event significantly predicted lower intergroup trust. Greater RWA and intergroup anxiety also significantly predicted lower intergroup trust. SDO was not a significant unique predictor. In Step 2, the interactions between temporal distance and RWA, SDO, or intergroup anxiety, were all nonsignificant.

Attitudes toward Muslims. Being closer to the event predicted less favourable attitudes. Greater SDO and intergroup anxiety also significantly uniquely predicted less favourable attitudes. Contrary to predictions and the results for intergroup trust, RWA was not a unique predictor. The interactions between temporal distance with RWA or SDO in Step 2 were not significant. However, the interaction between temporal distance and intergroup anxiety was at $p=.05$. Simple slopes analyses showed that greater intergroup anxiety was associated with less favourable attitudes towards Muslims both among those who completed the study further from the event $[b=-.34$ (CI: $-.53,-.15), p<.001]$ and those closer to the event $[b=-.60$ (CI: $-.78,-$ $.42), p<.001]$. However, the relation was stronger among those who completed it closer to the event (see Figure 1).

\section{Discussion}


Consistent with hypotheses and previous research (Imoff \& Recker, 2012; Lee et al., 2013; Uenal, 2016), greater right-wing ideology related to lower outgroup trust and more negative Muslim attitudes. Intergroup anxiety uniquely predicted intergroup trust and Muslim attitudes, consistent with previous research (e.g. White et al., 2012). RWA (but not SDO) uniquely predicted intergroup trust, and SDO (but not RWA) uniquely predicted Muslim attitudes. Of particular interest, even when entered alongside ideology and intergroup emotions in regression analyses, those who completed the survey closer to (vs. further from) the event reported less positive attitudes. Objective temporal distance only moderated the relation between intergroup anxiety and Muslim attitudes. As expected, the negative relation was stronger among those who completed the study closer (vs. further) to the shootings, suggesting that close temporal distance to terrorist attacks might exacerbate relations between intergroup emotions and prejudice. These findings extend research by Fischer et al. (2007), showing intergroup implications of objective temporal distance. Specifically, these results suggest that intolerance in response to a terror event may dissipate with time. Importantly, these results were observed even though there was no explicit mention of the shootings in the study.

\section{Study 2}

Study 2 allowed us to test our hypotheses and differed from Study 1 in three key ways. First, intergroup disgust (ITG-DS) was also examined as an additional intergroup emotion predictor. Second, Islamophobia (i.e. fear of Muslims and Islam, Lee et al., 2009) and attitudes concerning the restriction of civil liberties were added as intergroup outcomes variables. Third, and most pertinent to the present research, objective temporal distance was operationalised as the first five weeks following the shootings (i.e. closer to the event) compared to five months after the shootings (i.e. further from the event). This greater time difference between closer and farther 
objective temporal distance relative to the operationalization in Study 1 facilitated a better test of the intergroup implications of temporal distance. Those who completed the study within the first five weeks (vs. 5 months later) following the shootings were expected to report more negative opinions. Further, the relations between ideology and intergroup emotions with the outcome variables were expected to be stronger among those closer versus further from the event.

\section{Method}

Participants and procedure. Undergraduate students $(n=492)$ at a university in southern Ontario (Canada) completed a survey online in exchange for course credit. These participants had not participated in Study 1. Some participants $(n=20)$ provided incomplete data; where 80\% of the items were completed, a score was created. Almost all participants (94.1\%) reported that they were familiar with the October 22 shooting.

Measures. Similar to Study 1, RWA $(\alpha=.81)$, SDO $(\alpha=.93)$, intergroup anxiety $(\alpha=$ $.92)$, intergroup trust $(\alpha=.94)$, and attitudes towards Muslims $(\alpha=.92)$ were measured. Additionally, a dichotomous temporal distance variable was calculated, and participants completed measures of distress of terror events, ITG-DS, Islamophobia, and attitudes towards the restriction of civil liberties.

Distress of terror events. Participants indicated how distressed they felt about the shootings on Canadian Parliament, the 9/11 attacks, the London bombings of July $7^{\text {th }}, 2005$, and the possibility of a future terrorist attack on a scale from 1 (not at all distressed) to 7 (extremely distressed).

Objective temporal distance. A dichotomous objective temporal distance variable was calculated, as responses only occurred within one of two distinct periods of time after the shooting on Canadian Parliament. Responses that occurred from 5 to 40 days after the shootings 
were categorized as close to the event, and responses that occurred 141 to 167 days were categorized as far from the event.

Intergroup disgust sensitivity (ITG-DS). Participants completed the eight-item Intergroup Disgust Sensitivity scale (Hodson et al. 2013), and responded to items on a scale from 1 (strongly disagree) to 7 (strongly agree). Items were modified to reflect interactions with Muslims specifically, replacing "ethnic group" with "Muslims" (e.g. "When socializing with Muslims, one can easily become tainted by their stigma"). Higher average scores indicated greater ITG-DS with respect to interactions with Muslims $(\alpha=.74)$.

Islamophobia. Participants completed the 16-item Islamophobia scale (Lee et al., 2009). Participants indicated how much they agreed with statements, such as "Just to be safe, it is important to stay away from places where Muslims could be" on a scale from 1 (strongly disagree) to 5 (strongly agree). Higher average scores indicated greater Islamophobia, or fear of Muslims and Islam $(\alpha=.97)$.

Restriction of civil liberties. Participants completed a 13-item measure (e.g. item: "For improvement of protection from possible future terrorist attacks it is necessary to develop a stronger means of control in our country”) (Choma et al., 2015). Participants indicated how much they agreed with each statement on a scale from 1 (strongly disagree) to 7 (strongly agree). Higher scores indicated greater endorsement of the restriction of civil liberties $(\alpha=.74)$.

\section{Results}

Means, standard deviations and correlations among study variables are reported in Table 3. There was one univariate outlier for Islamophobia. Islamophobia was skewed, and SDO showed some kurtosis; therefore, bootstrapping was performed using 1000 samples (Field, 2013). Consistent with predictions, greater RWA and SDO were associated with less intergroup 
trust, less favourable attitudes towards Muslims, greater Islamophobia, and stronger endorsement of the restriction of civil liberties. Further, greater intergroup anxiety and ITG-DS related to lower intergroup trust, less favourable attitudes towards Muslims, greater Islamophobia, and greater support for restricting civil liberties. Participants perceived the October 22 shootings $(M=5.29, S D=2.53)$, the $9 / 11$ attacks $(M=5.59, S D=2.70)$, the London bombings $(M=4.37$, $S D=2.63)$, and the possibility of a future terrorist attack $(M=6.03, S D=2.69)$ as being distressing events at the time of doing the study (there were no differences in the means between the two time periods).

Mean-level differences between temporal periods. To determine whether intergroup trust, attitudes towards Muslims, Islamophobia and endorsement of the restriction of civil liberties differed by temporal distance from the shootings, one-way ANOVAs using bootstrapping with 1000 samples were conducted, with temporal distance as the between-subject variable (see Table 4). As expected, intergroup trust was lower, attitudes were less favourable, Islamophobia was higher, and endorsement of the restriction of civil liberties was higher among those who completed the study within 5 weeks (vs. 5 months) of the shootings.

Regression analyses. Hierarchical regression analyses were conducted for each criterion variable. Categorical temporal distance $(5-40$ days $=-1 ; 141-167$ days $=+1)$ and standardized RWA, SDO, intergroup anxiety, and ITG-DS were entered in Step 1 and the interaction terms were entered on Step 2. Bootstrapping using 1000 samples was used, with simple slopes analyses used to probe significant interactions. Results are reported in Table 5.

Intergroup trust. As predicted, being closer to the event, higher in RWA, SDO, intergroup anxiety, or ITG-DS significantly predicted less intergroup trust. In Step 2, the only significant interaction was between temporal distance and ITG-DS. The relation between greater 
ITG-DS and less intergroup trust was only significant among those who completed the study within 5 weeks of the event, $b=-.43$ (95CI: $-.60, .26), p<.001$, but not among those further from the event, $b=-.13$ (95CI: $-.38, .14), p=.320$.

Attitudes toward Muslims. As predicted, being closer to the shooting, being higher in SDO, intergroup anxiety, or ITG-DS significantly predicted more negative attitudes toward Muslims. RWA was not a unique predictor. In Step 2, none of the interactions were significant $(p s>.078)$

Islamophobia. Being closer to the event marginally predicted greater Islamophobia $(p=.055)$. As predicted, greater RWA, SDO, intergroup anxiety, or ITG-DS, uniquely predicted greater Islamophobia. In Step 2, the interactions were all non-significant ( $p s>.317)$.

Restriction of civil liberties. Being closer to the event, being higher in RWA, SDO, or intergroup anxiety significantly predicted support for restricting civil liberties. ITG-DS was not a significant predictor. In Step 2, the interactions between temporal distance with RWA or SDO were not significant. The interactions between temporal distance with intergroup anxiety, and with ITG-DS, were significant. The association between intergroup anxiety and civil liberties attitudes was positive among those who completed the study approximately 5 months after the event, $b=.24$ (95CI: .11,.36), $p<.001$, but non-significant among those who completed the study less than 5 weeks after the event, $p=.749$. The relation between ITG-DS and civil liberties attitudes was positive among those who completed the study closer to the event, $b=.15$ (95CI: $.05, .25), p=.004$, and not significant among those who completed the survey approximately 5 months after the event, $p=.363$.

\section{Discussion}


The objective temporal distance variable in Study 2 captured a greater time difference following the shootings (i.e. within 5 weeks vs. 5 months). As expected, and consistent with other research (i.e. Fischer et al., 2007), those who completed the study closer to the shootings reported lower intergroup trust, less favourable evaluations, greater Islamophobia, and were more supportive of restricting civil liberties. There was also some evidence that objective temporal distance might moderate the relation between intergroup emotions with intergroup trust or attitudes about civil liberties. ITG-DS interacted with objective temporal distance to predict intergroup trust, such that the relation between greater ITG-DS and lower intergroup trust was stronger among those who completed the study closer to the event, consistent with expectations. ITG-DS and intergroup anxiety interacted with objective temporal distance to predict support for the restriction of civil liberties. As with intergroup trust, the relation between ITG-DS and civil liberties was stronger among those closer to the event. Unexpectedly, greater intergroup anxiety related to greater support for the restriction of civil liberties only among those who completed the study further from the event. There was no relation among those closer to the event.

Greater right-wing ideology and intergroup emotions related moderately or strongly to lower outgroup trust, less positive attitudes, Islamophobia and endorsement of the restriction of civil liberties, adding to literature showing a link between ideology and intergroup emotions with anti-Muslim prejudice (Imoff \& Recker, 2012; Lee et al., 2013; Uenal, 2016; White et al., 2012). Intergroup anxiety and SDO uniquely predicted all dependent measures; intergroup anxiety was also the strongest predictor of intergroup trust and Muslim attitudes compared to RWA, SDO, and ITG-DS. As hypothesized, and consistent with other research (e.g. Hodson et al., 2013), ITG-DS uniquely predicted less intergroup trust, less positive Muslim attitudes, and was the strongest predictor of Islamophobia. ITG-DS did not uniquely predict support for the restriction 
of civil liberties. RWA uniquely predicted lower intergroup trust, greater Islamophobia, and greater endorsement of restricting civil liberties. RWA was also the strongest predictor of civil liberties attitudes. RWA did not uniquely predict Muslim attitudes. Thus, Study 2 shows that temporal distance, ideology, and intergroup emotions are all important for understanding Muslim/Islam sentiment and public policy attitudes in the wake of terror events.

\section{General Discussion}

Personal and social implications of being objectively temporally close to (vs. far from) terror events have been documented (Fischer et al., 2007; Stein et al., 2004). In the wake of the shootings at the Canadian Parliament, we considered prejudice and public policy attitude implications of being closer or further from terror events, and the role of ideology and intergroup emotions.

Being closer to (vs. further from) the shootings related to greater prejudice and lower intergroup trust, with the exception of Muslim attitudes in Study 1. Also, those who completed the survey five weeks (vs. 5 months) after the event were more supportive of restricting civil liberties, consistent with research showing a push for right-leaning policies in the wake of terrorism (e.g. Davis \& Silver, 2004; Huddy \& Feldman, 2011; Morgan et al., 2011; Whitehead \& Aden, 2001). Hence, objective temporal distance has prejudice and policy-relevant implications. Indeed, our results present the possibility that the documented 'conservative shift' in response to threat might not be particularly long lasting. This is an important area of future research best suited for a longitudinal design.

The present studies also highlight the relevance of individual differences. Those higher (vs. lower) in RWA and in SDO held less favourable attitudes of Muslims and reported greater Islamophobia, or fear of Muslims and Islam (Study 2), consistent with research showing a link 
between authoritarian ideologies and prejudice (e.g. Duckitt, 2001; Duckitt \& Sibley, 2017; Imoff \& Recker, 2012; Lee et al., 2013; Uenal, 2016). Similar to research in the intergroup contact literature (e.g. Hutchison \& Rosenthal, 2001; Islam \& Hewstone, 1993; Tausch et al., 2009), individuals who reported feeling anxious about interacting with a Muslim reported greater prejudice. Further, individuals reporting revulsion and disgust reactions towards Muslims also reported greater prejudice consistent with previous research (Choma et al., 2012; Choma et al., 2016; Hodson et al., 2013). Thus, ideology and intergroup emotions are relevant for understanding prejudice toward Muslims and Islam. Although specific patterns varied by criterion variable, ideology and intergroup emotions uniquely accounted for prejudice (and intergroup trust), with intergroup anxiety and ITG-DS as particularly robust predictors.

Limited research has examined the relation between ideology and intergroup emotions with intergroup trust (for exceptions, see Dhont \& van Hiel, 2011; Hodson et al., 2015). Outgroup trust is an important variable in intergroup relationships as it facilitates positive behavioural intentions and less dehumanization of outgroups in intergroup contact situations (Tam et al., 2009; Kenworthy et al., 2016; Vezzali et al., 2012). We found that individuals higher on RWA, SDO, intergroup anxiety, or ITG-DS were less trusting of Muslims. This finding highlights that interventions aimed at increasing intergroup trust among authoritarian individuals and those prone to experience intergroup anxiety and disgust might serve to promote positive intergroup relations.

There was no evidence that objective temporal distance affects the relation between rightwing ideology and prejudice. Objective temporal distance did, however, interact with intergroup emotions for some of the prejudice variables. The pattern of interactions with objective temporal distance for intergroup anxiety predicting Muslims attitudes in Study 1 and for ITG-DS 
predicting intergroup trust in Study 2 was the same: The intergroup emotions-prejudice connection was more pronounced for those who completed the study closer to (vs. further from) the event. This is conceptually consistent with Choma et al. (2012) who noted that the relation between ITG-DS and Islamophobia was strongest in a fear-inducing condition.

Those higher in RWA, SDO, intergroup anxiety or intergroup disgust also endorsed restricting civil liberties. However, in terms of unique predictive ability, ITG-DS was not a significant unique predictor, and RWA emerged as the strongest predictor of restricting civil liberties. Objective temporal distance moderated the relations between intergroup anxiety or ITG-DS with attitudes towards the restriction of civil liberties in Study 2. For the interaction with ITG-DS, endorsement of restricting civil liberties was strongest among those closer to the event, and not significant among those far from the event, suggesting that ITG-DS might be most relevant to such attitudes when threat is salient, as expected.

Unexpectedly, the relation between greater intergroup anxiety and supporting the restriction of civil liberties was only significant among those further from the event. These findings present the possibility that those lower in intergroup anxiety increase their endorsement of restricting civil liberties only during times of threat (i.e. closer to the event). Other research examining moral foundations, for instance, has found that liberals report greater endorsement of the ingroup moral foundation (a moral foundation typically more supported by those on the political right) following the July 7, 2015 bombings in London (Van de Vyver et al., 2016). Future research is needed to explore the potential moderating role of objective temporal distance as the results from the present research are mixed. It is worth highlighting, however, that the observed interactions with objective temporal distance were those involving intergroup 
emotions, and not ideology. This potentially suggests that the temporal effects of terrorist events with emotions may be more nuanced than those with ideology and warrant closer examination.

Some limitations of the present research should be noted. First, the samples primarily consisted of female university students from a multicultural city (Toronto) with relatively lower right-wing ideology and relatively tolerant intergroup attitudes. This affects the external validity of the studies and the ability for them to account and control for possible demographic differences across measures. Moreover, although the events of October 22, 2014 likely affected all Canadians, it is possible that results might differ for those who were living in Ottawa at the time of the shootings as the event would have also been physically closer and as a result potentially more threatening. Indeed, research on construal level theory shows that things spatially further away can feel more distant (Liberman \& Trope, 2008). The specific temporal periods examined in the present research were somewhat restricted by the constraints of the undergraduate research pool used to recruit participants. As a result, in Study 2, a dichotomous measure of temporal distance had to be created as the responses fell into temporal clusters. In the future, it would be informative to examine a continuous measure of temporal distance to consider whether the effect is linear over time. In Study 2, participants were asked if they were familiar with the event and their distress associated with terror events; while informative, this might have also primed participants to consider how far away (temporally or geographically) from the event and this may have influenced their responses.

Finally, actual temporal distance was explored instead of subjective temporal distance (i.e. how far a person perceives something to be). Research on subjective temporal distance shows perceptions of distance have implications for wellbeing (e.g. Busseri, Choma, \& Sadava, 2009; Skinner \& Brewer, 2002; Gilovich, Kerr, \& Medvec, 1993, Ross \& Wilson, 2002; 
Wakimoto, 2011; Rush \& Grouzet, 2012; Wilson \& Ross, 2001; Levine, Whalen, Henker, \& Jamner, 2005). Research has also shown that re-exposure to footage of terrorist events can recalibrate perceptions of distress/threat and this predicts greater prejudice and support for restricting civil liberties (Choma et al., 2015). Thus, even though people might be temporally far from an event, perceiving the event as close could similarly have social implications.

\section{Conclusion}

The present research contributes to existing literature in three ways. First, temporal distance has implications for prejudice and public policy attitudes, not just wellbeing and social outcomes. Second, it shows that ideology and intergroup emotions uniquely account for intergroup and public policy attitudes. Third, temporal distance can moderate relations between ideology and intergroup emotions. In general, the present research shows the complexity of psychological variables underlying intergroup and public policy attitudes, and the relevance of current terror events for intergroup relations. 
Table 1

Means, standard deviations and correlations between Study 1 variables

\begin{tabular}{lllllll}
\hline & M (SD) & 1 & 2 & 3 & 4 & 5 \\
\hline 1. Temporal distance & $150.33(8.23)$ & & & & \\
2. RWA & $2.69(1.00)$ & -.07 & & & & \\
3. SDO & $2.18(0.95)$ & -.04 & $.53^{* *}$ & & & \\
4. ITG-ANX & $2.61(1.10)$ & .05 & $.31^{* *}$ & $.36^{* *}$ & & \\
5. ITG-Trust & $5.38(1.25)$ & $.15^{*}$ & $-.36^{* *}$ & $-.33^{* *}$ & $-.46^{* *}$ & \\
6. Attitudes toward Muslims & $4.98(1.05)$ & .11 & $-.27^{* *}$ & $-.36^{* *}$ & $-52^{* *}$ & $.70^{* *}$
\end{tabular}

Note. $N=214$. Bootstrapping with 1000 samples was used with $95 \%$ confidence intervals. $\mathrm{RWA}=$ right-wing authoritarianism; $\mathrm{SDO}=$ social dominance orientation; ITG-ANX=intergroup anxiety; ITG-Trust $=$ intergroup trust. 


\section{Table 2}

Regression results for Study 1

\begin{tabular}{|c|c|c|c|c|c|c|c|c|c|c|c|c|}
\hline & \multicolumn{6}{|c|}{ Intergroup Trust } & \multicolumn{6}{|c|}{ Muslim Attitude } \\
\hline & \multicolumn{3}{|c|}{ Step 1} & \multicolumn{3}{|c|}{ Step 2} & \multicolumn{3}{|c|}{ Step 1} & \multicolumn{3}{|c|}{ Step 2} \\
\hline & $b$ & $C I$ & $s r^{2}$ & $b$ & $C I$ & $s r^{2}$ & $b$ & $C I$ & $s r^{2}$ & $b$ & $C I$ & $s r^{2}$ \\
\hline Temporal Distance & $.19 * *$ & $.04, .33$ & .02 & $.22 * *$ & $.07, .36$ & .03 & $.12 *$ & $.004, .24$ & .01 & $.14^{*}$ & $.02, .26$ & .02 \\
\hline RWA & $-.23 * *$ & $-.40,-.06$ & .02 & $-.25 * *$ & $-.43,-.08$ & .03 & -.02 & $-.16, .12$ & .00 & -.04 & $-.18, .11$ & .00 \\
\hline SDO & -.12 & $-.29,06$ & .001 & -.09 & $-.27, .08$ & .001 & $-.19 * *$ & $-.34,-.05$ & .02 & $-.17 *$ & $-.32,-.03$ & .02 \\
\hline Intergroup Anxiety & $-.47 * *$ & $-.63,-.32$ & .12 & $-.49 * *$ & $-63,-.31$ & .12 & $-.48 * *$ & $.60,-.35$ & .17 & $-.47 * *$ & $-.60,-.34$ & .17 \\
\hline RWA x TD & & & & -.10 & $-.26, .06$ & .005 & & & & -.06 & $-.19, .07$ & .00 \\
\hline SDO $x$ TD & & & & -.10 & $-.28, .09$ & .004 & & & & -.10 & $-.25, .05$ & .005 \\
\hline ITGANX x TD & & & & .13 & $-.03, .28$ & .01 & & & & $.13^{*}$ & $.00, .26$ & .01 \\
\hline$R^{2}$ & & & $.30 * *$ & & & .32 & & & $.32 * *$ & & & .34 \\
\hline$R^{2}$ Change & & & & & & .02 & & & & & & .02 \\
\hline
\end{tabular}




\section{Table 3}

Means, standard deviations and correlations between Study 2 variables

\begin{tabular}{|c|c|c|c|c|c|c|c|c|}
\hline & $\mathrm{M}(\mathrm{SD})$ & 1 & 2 & 3 & 4 & 5 & 6 & 7 \\
\hline 1. RWA & $2.94(1.03)$ & & & & & & & \\
\hline 2. SDO & $2.33(1.12)$ & $.51 * *$ & & & & & & \\
\hline 3. ITG-ANX & $2.86(1.26)$ & $.30 * *$ & $.47 * *$ & & & & & \\
\hline 4. ITG-DS & $2.16(1.01)$ & $.41 * *$ & $.52 * *$ & $.55 * *$ & & & & \\
\hline 5. ITG-Trust & $5.25(1.52)$ & $-.34 * *$ & $-.45 * *$ & $-.52 * *$ & $-.50 * *$ & & & \\
\hline 6. Attitudes toward Muslims & $4.91(1.25)$ & $-.30 * *$ & $-.49 * *$ & $-.63 * *$ & $-.52 * *$ & $.66^{* *}$ & & \\
\hline 7. Islamophobia & $1.61(0.81)$ & $.44 * *$ & $.59 * *$ & $.57 * *$ & $.66^{* *}$ & $-.52 * *$ & $-.61 * *$ & \\
\hline 8. Restriction of civil liberties & $3.67(0.83)$ & $.45^{* *}$ & $.38 * *$ & $.33 * *$ & $.35 * *$ & $-.25 * *$ & $-.32 * *$ & $.31 * *$ \\
\hline
\end{tabular}

Note. $N=468$ because of missing values for RWA. Bootstrapping with 1000 samples was used with $95 \%$ confidence intervals. $\mathrm{RWA}=$ right-wing authoritarianism; SDO=social dominance orientation; ITG-ANX=intergroup anxiety; ITG-DS=intergroup disgust sensitivity; ITG-Trust = intergroup trust. 
Islamoprejudice 29

Table 4

Results of one-way ANOVA on intergroup attitudes

\begin{tabular}{lcccccc}
\hline & $\begin{array}{c}5-40 \text { days } \\
\text { M (SD) }\end{array}$ & $\begin{array}{c}141-167 \text { days } \\
\text { M (SD) }\end{array}$ & $F$ & $d f$ & $p$ & $d$ \\
\hline 1. ITG-Trust & $5.12(1.53)$ & $5.53(1.47)$ & 8.10 & 1,475 & .005 & .27 \\
& & & & & & \\
2. Attitudes toward Muslims & $4.79(1.19)$ & $5.14(1.31)$ & 8.71 & $1,338.66$ & .003 & .28 \\
3. Islamophobia & $1.68(0.82)$ & $1.50(0.77)$ & 5.78 & $1,387.13$ & .017 & .22 \\
4. Restriction of civil liberties & $3.74(0.78)$ & $3.52(0.88)$ & 7.97 & 1,475 & .005 & .27
\end{tabular}

Note. $N=301$ for 5-40 day group, $N=176$ for the 141-167 group. Welch test are reported for Muslim attitude and Islamophobia as equality of means was violated. The d values have been corrected for unequal sample sizes. 


\section{Table 5}

Regression Results for Study 2

\begin{tabular}{|c|c|c|c|c|c|c|c|c|c|c|c|c|}
\hline & \multicolumn{6}{|c|}{ Intergroup Trust } & \multicolumn{6}{|c|}{ Muslim Attitude } \\
\hline & \multicolumn{3}{|c|}{ Step 1} & \multicolumn{3}{|c|}{ Step 2} & \multicolumn{3}{|c|}{ Step 1} & \multicolumn{3}{|c|}{ Step 2} \\
\hline & $b$ & $C I$ & $s r^{2}$ & $b$ & $C I$ & $s r^{2}$ & $b$ & $C I$ & $s r^{2}$ & $b$ & $C I$ & $s r^{2}$ \\
\hline Temporal Distance & $.15^{*}$ & $.03, .26$ & .01 & $.15^{*}$ & $.03, .26$ & .01 & $.12 * *$ & $.03, .20$ & .01 & $.12 * *$ & $.03, .20$ & .01 \\
\hline RWA & $-.13^{*}$ & $-.27,-.003$ & .01 & -.09 & $-.23, .05$ & .00 & -.001 & $-.10, .10$ & .00 & .03 & $-.07, .13$ & .00 \\
\hline SDO & $-.21 * *$ & $-.36,-.07$ & .01 & $-.27 * *$ & $-.42,-.12$ & .02 & $-.23 * *$ & $-.34,-.13$ & .02 & $-.24 * *$ & $-.36,-.13$ & .02 \\
\hline Intergroup Anxiety & $-.45 * *$ & $-.59,-.32$ & .06 & $-.44 * *$ & $-.58,-.30$ & .05 & $-.55 * *$ & $-.65,-.44$ & .12 & $-.54 * *$ & $-.64,-.43$ & .12 \\
\hline ITG-DS & $-.33 * *$ & $-.47,-.18$ & .03 & $-.28 * *$ & $-.42,-.13$ & .02 & $-.22 * *$ & $-.33,-.12$ & .02 & $-.24 * *$ & $-.36,-.13$ & .02 \\
\hline RWA $x$ TD & & & & .10 & $-.04, .24$ & .002 & & & & .09 & $-.01, .20$ & .004 \\
\hline SDO $x$ TD & & & & -.15 & $-.30, .00$ & .005 & & & & .01 & $-.10, .13$ & .00 \\
\hline ITG-ANX x TD & & & & .01 & $-.13, .15$ & .00 & & & & .003 & $-.10, .11$ & .00 \\
\hline ITG-DS x TD & & & & $.15^{*}$ & $.003, .30$ & .01 & & & & -.07 & $-.18, .04$ & .002 \\
\hline$R^{2}$ & & & $.37^{* *}$ & & & .38 & & & $.47^{* *}$ & & & .48 \\
\hline$R^{2}$ Change & & & & & & .01 & & & & & & .005 \\
\hline
\end{tabular}




\begin{tabular}{|c|c|c|c|c|c|c|c|c|c|c|c|c|}
\hline & \multicolumn{6}{|c|}{ Islamophobia } & \multicolumn{6}{|c|}{ Civil Liberties Attitudes } \\
\hline & \multicolumn{3}{|c|}{ Step 1} & \multicolumn{3}{|c|}{ Step 2} & \multicolumn{3}{|c|}{ Step 1} & \multicolumn{3}{|c|}{ Step 2} \\
\hline & $b$ & $C I$ & $s r^{2}$ & $b$ & $C I$ & $s r^{2}$ & $b$ & $C I$ & $s r^{2}$ & $b$ & $C I$ & $s r^{2}$ \\
\hline Temporal Distance & -.05 & $-.10, .001$ & .00 & -.05 & $-.10, .001$ & .004 & $-.10 * *$ & $-.17,-.03$ & .01 & $-.10^{* *}$ & $-.17,-.04$ & .01 \\
\hline RWA & $.08 * *$ & $.02, .14$ & .01 & $.08^{*}$ & $.02, .14$ & .01 & $.27 * *$ & $.19, .35$ & .08 & $.30 * *$ & $.22, .38$ & .08 \\
\hline SDO & $.19 * *$ & $.13, .25$ & .03 & $.19^{* *}$ & $.12, .25$ & .03 & $.09^{*}$ & $.003, .17$ & .01 & .07 & $-.01, .16$ & .004 \\
\hline Intergroup Anxiety & $.17^{* *}$ & $.11, .23$ & .03 & $.17^{* *}$ & $.11, .23$ & .03 & $.11 * *$ & $.03, .19$ & .01 & $.13 * *$ & $.05, .21$ & .01 \\
\hline ITG-DS & $.30^{* *}$ & $.23, .36$ & .08 & $.30^{* *}$ & $.23, .36$ & .07 & .06 & $-.02, .15$ & .004 & .04 & $-.05, .13$ & .001 \\
\hline RWA x TD & & & & -.03 & $-.09, .03$ & .001 & & & & .08 & $-.001, .16$ & .01 \\
\hline SDO x TD & & & & -.02 & $-.09, .04$ & .00 & & & & -.01 & $-.10, .08$ & .00 \\
\hline ITG-ANX x TD & & & & .03 & $-.03, .09$ & .001 & & & & $.11^{* *}$ & $.03, .19$ & .01 \\
\hline ITD-DS x TD & & & & -.003 & $-.07, .06$ & .00 & & & & $-.11^{*}$ & $-.19,-.02$ & .01 \\
\hline$R^{2}$ & & & $.55^{* *}$ & & & .56 & & & $.27 * *$ & & & $.29 *$ \\
\hline$R^{2}$ Change & & & & & & .003 & & & & & & .02 \\
\hline
\end{tabular}

Note. ${ }^{*} \mathrm{p}<.05,{ }^{* *} \mathrm{p}<.01 . \mathrm{RWA}=$ right-wing authoritarianism. SDO $=$ social dominance orientation. ITG-ANX=intergroup anxiety. ITG-DS = intergroup disgust sensitivity. TD=temporal distance. Standardized variables were used in analyses so regression coefficients can be interpreted as standardized coefficients. 


\section{Figure 1}

Interaction between temporal distance and intergroup anxiety on Muslim attitudes (Study 1)

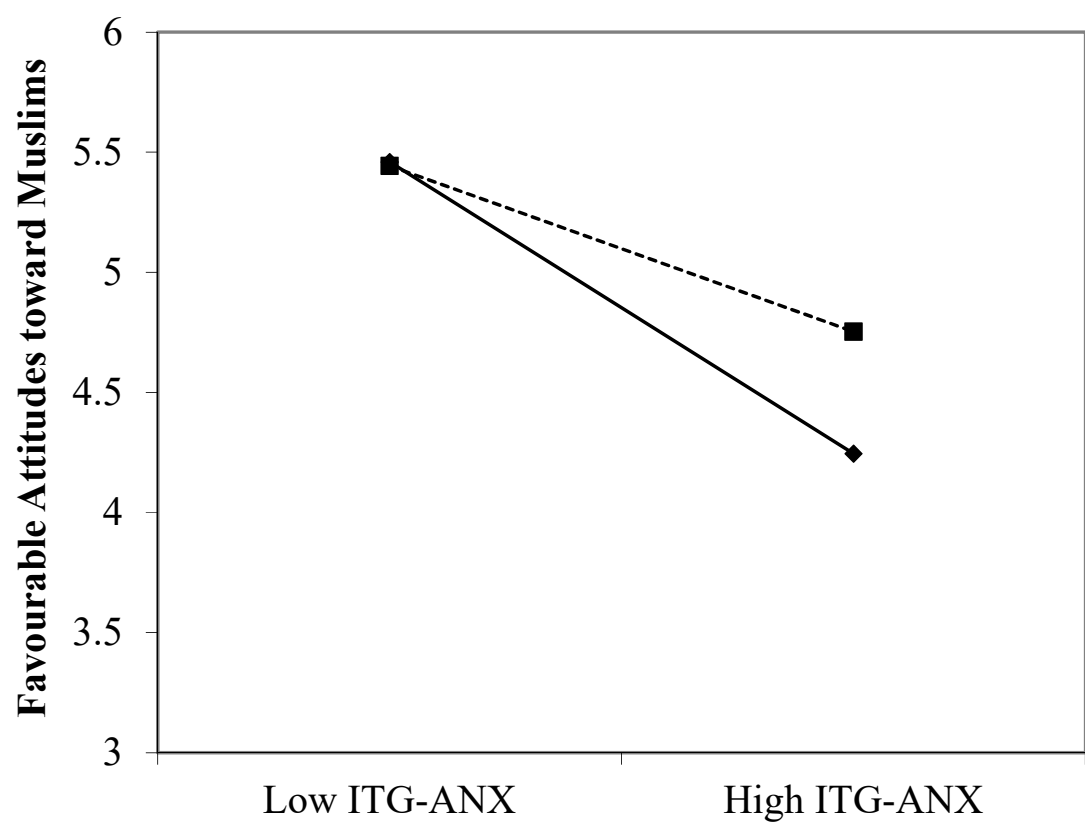




\section{References}

Altemeyer, B. (1981). Right-wing authoritarianism. University of Manitoba press.

Altemeyer, B. (1996). The authoritarian specter. Harvard University Press.

Altemeyer, B. (1998). The other "authoritarian personality". Advances in experimental social psychology, 30, 47-92. doi:10.1016/S0065-2601(08)60382-2

Asbrock, F., Sibley, C. G., \& Duckitt, J. (2010). Right-wing authoritarianism and social dominance orientation and the dimensions of generalized prejudice: A longitudinal test. European Journal of Personality, 24(4), 324-340. doi:10.1002/per.746

Busseri, M. A., Choma, B. L., \& Sadava, S. W. (2009). Functional or fantasy? Examining the implications of subjective temporal perspective "trajectories" for life satisfaction. Personality and Social Psychology Bulletin, 35(3), 295-308. doi:10.1177/0146167208327215

Bronskill, J. (2016, January 15). Mental breakdown not key factor in Parliament Hill shooting: RCMP head. The Globe and Mail. Retrieved from: https://www.theglobeandmail.com/news/national/mental-breakdown-not-key-factor-inparliament-hill-shooting-rcmp-head/article28213573/

Cantal, C., Milfont, T. L., Wilson, M. S., \& Gouveia, V. V. (2015). Differential effects of rightwing authoritarianism and social dominance orientation on dimensions of generalized prejudice in Brazil. European Journal of Personality, 29(1), 17-27. doi:10.1002/per.1978

CBC. (2014, October 20). Martin Rouleau, Quebec driver shot by police, 'radicalized': RCMP. Retrieved from http://www.cbc.ca/news/canada/montreal/martin-rouleau-quebecdriver-shot-by-police-radicalized-rcmp-1.2806104

Cehajic, S., Brown, R., \& Castano, E. (2008). Forgive and forget? Antecedents and 
consequences of intergroup forgiveness in Bosnia and Herzegovina. Political Psychology, 29(3), 351-367. doi:10.1111/j.1467-9221.2008.00634.x

Choma, B. L., Charlesford, J. J., Dalling, L., \& Smith, K. (2015). Effects of viewing 9/11 footage on distress and islamophobia: a temporally expanded approach. Journal of Applied Social Psychology, 45(6), 345-354. doi:10.1111/jasp.12300

Choma, B. L., Haji, R., Hodson, G., \& Hoffarth, M. (2016). Avoiding cultural contamination: Intergroup disgust sensitivity and religious identification as predictors of interfaith threat, faith-based policies, and islamophobia. Personality and Individual Differences, 95, 5055. doi:10.1016/j.paid.2016.02.013

Choma, B. L., Hodson, G., \& Costello, K. (2012). Intergroup disgust sensitivity as a predictor of islamophobia: The modulating effect of fear. Journal of Experimental Social Psychology, 48(2), 499-506. doi:10.1016/j.jesp.2011.10.014

Cottrell, C. A., \& Neuberg, S. L. (2005). Different emotional reactions to different groups: A sociofunctional threat-based approach to 'prejudice'. Journal of Personality and Social Psychology, 88(5), 770-789. doi:10.1037/0022-3514.88.5.770

Davis, D. W., \& Silver, B. D. (2004). Civil liberties vs. security: Public opinion in the context of the terrorist attacks on America. American Journal of Political Science, 48(1), 28-46. doi:10.1111/j.0092-5853.2004.00054.x

Dhont, K., \& Van Hiel, A. (2011). Direct contact and authoritarianism as moderators between extended contact and reduced prejudice: Lower threat and greater trust as mediators. Group Processes \& Intergroup Relations, 14(2), 223-237. doi:10.1177/1368430210391121

Doosje, B., Zimmermann, A., Küpper, B., Zick, A., \& Meertens, R. (2009). Terrorist threat and 
perceived Islamic support for terrorist attacks as predictors of personal and institutional out-group discrimination and support for anti-immigration policies-Evidence from 9 European countries. Revue Internationale De Psychologie Sociale, 22(3-4), 203-233.

Dovidio, J. F., Gaertner, S. L., Kawakami, K., \& Hodson, G. (2002). Why can't we just get along? Interpersonal biases and interracial distrust. Cultural Diversity \& Ethnic Minority Psychology, 8(2), 88-102. doi:10.1037//1099-9809.8.2.88

Duckitt, J. (2001). A dual-process cognitive-motivational theory of ideology and prejudice. Advances in Experimental Social Psychology, 33, 41-113. doi:10.1016/S00652601(01)80004-6

Duckitt, J. (2006). Differential effects of right wing authoritarianism and social dominance orientation on outgroup attitudes and their mediation by threat from and competitiveness to outgroups. Personality and Social Psychology Bulletin, 32(5), 684-696. doi: $10.1177 / 0146167205284282$

Duckitt, J., \& Sibley, C. G. (2007). Right wing authoritarianism, social dominance orientation and the dimensions of generalized prejudice. European Journal of Personality, 21(2), 113. doi:10.1002/per.614

Duckitt, J., \& Sibley, C. G. (2017). The dual process motivational model of ideology and prejudice. In C. G. Sibley \& F. K. Barlow (Eds.), The Cambridge handbook of the psychology of prejudice (pp. 188-221). Cambridge, UK: Cambridge University Press.

Duriez, B., Vansteenkiste, M., Soenens, B., \& De Witte, H. (2007). The social costs of extrinsic relative to intrinsic goal pursuits: Their relation with social dominance and racial and ethnic prejudice. Journal of Personality, 75(4), 757-782. doi:10.1111/j.14676494.2007.00456.x 
Federal Bureau of Investigation. (2015). Incidents, offenses, victims, and known offenders by bias motivation, 2015 [Data file]. Available from https://ucr.fbi.gov/hatecrime/2015/tables-and-data-declarations/1tabledatadecpdf

Field, A. (2013). Discovering statistics using IBM SPSS statistics ( ${ }^{\text {th }}$ ed.). Sage.

Fischer, P., Greitemeyer, T., Kastenmüller, A., Frey, D., \& Oßwald, S. (2007). Terror salience and punishment: Does terror salience induce threat to social order? Journal of Experimental Social Psychology, 43(6), 964-971. doi:10.1016/j.jesp.2006.10.004

Fischer, P., Greitemeyer, T., Kastenmuller, A., Jonas, E., \& Frey, D. (2006). Coping with terrorism: The impact of increased salience of terrorism on mood and self-efficacy of intrinsically religious and nonreligious people. Personality and Social Psychology Bulletin, 32(3), 365-377. doi:10.1177/0146167205282738

Fiske, S. T., Cuddy, A. J. C., Glick, P., \& Xu, J. (2002). A model of (often mixed) stereotype content: Competence and warmth respectively follow from perceived status and competition. Journal of Personality and Social Psychology, 82(6), 878-902. doi:10.1037/0022-3514.82.6.878

Gilovich, T., Kerr, M., \& Medvec, V. H. (1993). Effect of temporal perspective on subjective confidence. Journal of Personality and Social Psychology: Attitudes and Social Cognition, 64(4), 552-560. doi:10.1037/0022-3514.64.4.552

Hewstone, M., Cairns, E., Voci, A., Hamberger, J., \& Niens, U. (2006). Intergroup contact, forgiveness, and experience of 'the troubles' in Northern Ireland. Journal of Social Issues, 62(1), 99-120. doi:10.1111/j.1540-4560.2006.00441.x

Hodson, G., Choma, B. L., Boisvert, J., Hafer, C. L., MacInnis, C. C., \& Costello, K. (2013). The 
role of intergroup disgust in predicting negative outgroup evaluations. Journal of Experimental Social Psychology, 49(2), 195. doi:10.1016/j.jesp.2012.11.002

Hodson, G., Dube, B., \& Choma, B. L. (2015). Can (elaborated) imagined contact interventions reduce prejudice among those higher in intergroup disgust sensitivity (ITG-DS)? Journal of Applied Social Psychology, 45(3), 123-131. doi:10.1111/jasp.12281

Hodson, G., Esses, V.M., \& Dovidio, J.F. (2006). Perceptions of threat, national representation, and support for policies and procedures to protect the national group. In P.R. Kimmel \& C.E. Stout (Eds.), Collateral damage: The psychological consequences of America's war on terrorism (pp. 109-129). Westport, CT: Praeger Press.

Hodson, G., Hewstone, M., \& Swart, H. (2013). Advances in intergroup contact: Epilogue and future directions. In G. Hodson, \& M. Hewstone (Eds.), Advances in intergroup contact; advances in intergroup contact (pp. 262-305). New York, NY: Psychology Press.

Huddy, L., \& Feldman, S. (2011). Americans respond politically to 9/11: Understanding the impact of the terrorist attacks and their aftermath. American Psychologist, 66(6), 455. doi: $10.1037 / \mathrm{a} 0024894$

Huddy, L., Feldman, S., Taber, C., \& Lahav, G. (2005). Threat, anxiety, and support of antiterrorism policies. American journal of political science, 49(3), 593-608. doi:10.1111/j.1540-5907.2005.00144.x

Hutchison, P., \& Rosenthal, H. E. (2011). Prejudice against Muslims: Anxiety as a mediator between intergroup contact and attitudes, perceived group variability and behavioural intentions. Ethnic and Racial Studies, 34(1), 40-61. doi:01419871003763312

Imhoff, R., \& Recker, J. (2012). Differentiating islamophobia: Introducing a new scale to 
Islamoprejudice 38

measure islamoprejudice and secular Islam critique. Political Psychology, 33(6), 811824. doi:10.1111/j.1467-9221.2012.00911.x

Islam, M. R., \& Hewstone, M. (1993). Dimensions of contact as predictors of intergroup anxiety, perceived out-group variability, and out-group attitude: An integrative model. Personality and Social Psychology Bulletin, 19(6), 700. doi:10.1177/0146167293196005

Kauff, M., Asbrock, F., Issmer, C., Thörner, S., \& Wagner, U. (2015). When immigrant groups 'misbehave': The influence of perceived deviant behavior on increased threat and discriminatory intentions and the moderating role of right-wing authoritarianism. European Journal of Social Psychology, 45(5), 641-652. doi:10.1002/ejsp.2116

Kenworthy, J. B., Voci, A., Al Ramiah, A., Tausch, N., Hughes, J., \& Hewstone, M. (2016). Building trust in a postconflict society: An integrative model of cross-group friendship and intergroup emotions. Journal of Conflict Resolution, 60, 1041-1070.

Kteily, N. S., Sidanius, J., \& Levin, S. (2011). Social dominance orientation: Cause or 'mere effect'?: Evidence for SDO as a causal predictor of prejudice and discrimination against ethnic and racial outgroups. Journal of Experimental Social Psychology, 47(1), 208. doi:10.1016/j.jesp.2010.09.009

Lee, S. A., Gibbons, J. A., Thompson, J. M., \& Timani, H. S. (2009). The islamophobia scale: Instrument development and initial validation. International Journal for the Psychology of Religion, 19(2), 92-105. doi:10.1080/10508610802711137

Lee, S. A., Reid, C. A., Short, S. D., Gibbons, J. A., Yeh, R., \& Campbell, M. L. (2013). Fear of Muslims: Psychometric evaluation of the islamophobia scale. Psychology of Religion and Spirituality, 5(3), 157-171. doi:10.1037/a0032117 
Levine, L. J., Whalen, C. K., Henker, B., \& Jamner, L. D. (2005). Looking back on September 11, 2001: Appraised impact and memory for emotions in adolescents and adults. Journal of Adolescent Research, 20(4), 497-523. doi:10.1177/0743558405274893

Lewicki, R. J., McAllister, D. J., \& Bies, R. J. (1998). Trust and distrust: New relationships and realities. The Academy of Management Review, 23(3), 438-458. doi:10.2307/259288

Mackie, D. M., \& Smith, E. R. (2002). Intergroup emotions and the social self: Prejudice reconceptualized as differentiated reactions to outgroups. In J. P. Forgas \& K. D. Williams (Eds.), The social self: Cognitive, interpersonal, and intergroup perspectives (pp. 309-326). New York, NY: Psychology Press.

Miles, E., \& Crisp, R. J. (2014). A meta-analytic test of the imagined contact hypothesis. Group Processes \& Intergroup Relations, 17(1), 3-26. doi:10.1177/1368430213510573

Morgan, G. S., Wisneski, D. C., \& Skitka, L. J. (2011). The expulsion from Disneyland: The social psychological impact of 9/11. American Psychologist, 66(6), 447-454. doi:http://dx.doi.org/10.1037/a0024772

Norris, F. H., Friedman, M. J., Watson, P. J., Byrne, C. M., Diaz, E., \& Kaniasty, K. (2002). 60,000 disaster victims speak: Part I. An empirical review of the empirical literature, 1981-2001. Psychiatry: Interpersonal and biological processes, 65(3), 207-239. doi:10.1521/psyc.65.3.207.20173

Oswald, D. L. (2005). Understanding anti-arab reactions post-9/11: The role of threats, social categories, and personal ideologies. Journal of Applied Social Psychology, 35(9), 1775 1799. doi:10.1111/j.1559-1816.2005.tb02195.x

Paolini, S., Hewstone, M., Voci, A., Harwood, J., \& Cairns, E. (2006). Intergroup contact and the 
promotion of intergroup harmony: The influence of intergroup emotions. In R. Brown \& D. Capozza (Eds.), Social identities: Motivational, emotional, and cultural influences (pp. 209-238). New York, NY: Psychology Press.

Pettigrew, T. F., \& Tropp, L. R. (2008). How does intergroup contact reduce prejudice? Metaanalytic tests of three mediators. European Journal of Social Psychology, 38(6), 922-934. doi:10.1002/ejsp.504

Pratto, F., Sidanius, J., Stallworth, L. M., \& Malle, B. F. (1994). Social dominance orientation: A personality variable predicting social and political attitudes. Journal of Personality and Social Psychology, 67(4), 741-763. doi:10.1037/0022-3514.67.4.741

Pew Research Centre. (2014, September 10). Growing concern about rise of Islamic extremism at home and abroad. Retrieved from http:/www.people-press.org/2014/09/10/growingconcern-about-rise-of-islamic-extremism-at-home-and-abroad/

Riek, B. M., Mania, E. W., \& Gaertner, S. L. (2006). Intergroup threat and outgroup attitudes: A meta-analytic review. Personality and Social Psychology Review, 10(4), 336-353. doi:10.1207/s15327957pspr1004_4

Ross, M., \& Wilson, A. E. (2002). It feels like yesterday: Self-esteem, valence of personal past experiences, and judgments of subjective distance. Journal of Personality and Social Psychology, 82(5), 792-803. doi:10.1037/0022-3514.82.5.792

Rozin, P., Haidt, J., \& McCauley, C. R. (2008). Disgust. In M. Lewis, J. M. Haviland-Jones \& L. F. Barrett (Eds.), Handbook of emotions (3rd ed.) (pp. 757-776). New York, NY: Guildford Press.

Rush, J., \& Grouzet, F. M. E. (2012). It is about time: Daily relationships between temporal 
perspective and well-being. The Journal of Positive Psychology, 7(5), 427-442. doi:10.1080/17439760.2012.713504

Schaller, M., \& Park, J. H. (2011). The behavioral immune system (and why it matters). Current Directions in Psychological Science, 20(2), 99-103. doi:10.1177/0963721411402596

Sibley, C. G., \& Duckitt, J. (2008). Personality and prejudice: A meta-analysis and theoretical review. Personality and Social Psychology Review, 12(3), 248-279. doi:10.1177/1088868308319226

Sibley, C. G., Wilson, M. S., \& Duckitt, J. (2007). Effects of dangerous and competitive worldviews on right-wing authoritarianism and social dominance orientation over a fivemonth period. Political Psychology, 28(3), 357-371. doi:10.1111/j.14679221.2007.00572.x

Sidanius, J., Cotterill, S., Sheehy-Skeffington, J., Kteily, N., \& Carvacho, H. (2017). Social dominance theory: Explorations in the psychology of oppression. In C. G. Sibley \& F. K. Barlow (Eds.), The Cambridge handbook of the psychology of prejudice (pp. 149-187). Cambridge, UK: Cambridge University Press.

Sidanius, J., Levin, S., Federico, C., \& Pratto, F. (2001). Social dominance approach. In J. T. Jost \& B. Majo (Eds), Psychology of legitimacy: Emerging perspectives on Ideology, Justice, and Intergroup Relations (pp. 307-322). Cambridge, UK: Cambridge University Press.

Sidanius, J., \& Pratto, F. (1999). Social dominance: An intergroup theory of social hierarchy and oppression. Cambridge, UK: Cambridge University Press.

Skinner, N., \& Brewer, N. (2002). The dynamics of threat and challenge appraisals prior to 
stressful achievement events. Journal of Personality and Social Psychology: Personality Processes and Individual Differences, 83(3), 678-692. doi:http://dx.doi.org/10.1037/0022-3514.83.3.678

Skitka, L. J., Bauman, C. W., \& Mullen, E. (2004). Political tolerance and coming to psychological closure following the September 11, 2001, terrorist attacks: An integrative approach. Personality and Social Psychology Bulletin, 30(6), 743-756. doi:10.1177/0146167204263968

Slone, M. (2000). Responses to media coverage of terrorism. Journal of Conflict Resolution, 44(4), 508-522. doi:10.1177/0022002700044004005

Stein, B. D., Jaycox, L. H., Elliott, M. N., Collins, R., Berry, S., Marshall, G. N., ... \& Schuster, M. A. (2004). The emotional and behavioral impact of terrorism on children: Results from a national survey. Applied Developmental Science, 8(4), 184-194. doi:10.1207/s1532480xads0804_2

Stephan, W. G. (2014). Intergroup anxiety: Theory, research, and practice. Personality and Social Psychology Review, 18(3), 239-255. doi:10.1177/1088868314530518

Stephan, W. G., \& Renfro, C. L. (2002). The role of threat in intergroup relations. In D. M. Mackie \& E. R. Smith (Eds.), From prejudice to intergroup emotions: Differentiated reactions to social groups (pp. 191-207). New York, NY: Psychology Press.

Stephan, W. G., \& Stephan, C. W. (1985). Intergroup anxiety. Journal of Social Issues, 41(3), 157-175. http://doi.org/10.1111/j.1540-4560.1985.tb01134.x

Stephan, W. G., \& Stephan, C. W. (2000). An integrated threat theory of prejudice. In S. Oskamp (Ed.), Reducing prejudice and discrimination (pp. 23-45). Lawrence Erlbaum Associates. Strobel, W. (2015, June 19). Terror attacks, deaths up sharply in 2014 - U.S. State Department. 
Retrieved from http://www.reuters.com/article/usa-terrorismidUSKBN0OZ25L20150619

Tam, T., Hewstone, M., Kenworthy, J., \& Cairns, E. (2009). Intergroup trust in Northern Ireland. Personality and Social Psychology Bulletin, 35(1), 45. doi:10.1177/0146167208325004

Tausch, N., Hewstone, M., \& Roy, R. (2009). The relationships between contact, status and prejudice: An integrated threat theory analysis of Hindu-Muslim relations in India. Journal of Community and Applied Social Psychology, 19(2), 83-94. doi:10.1002/casp.984

Tausch, N., Hewstone, M., Schmid, K., Hughes, J., \& Cairns, E. (2011). Extended contact effects as a function of closeness of relationship with ingroup contacts. Group Processes and Intergroup Relations, 14(2), 239-254. doi:10.1177/1368430210390534

Techakesari, P., Barlow, F., Hornsey, M., Sung, B., Thai, M., \& Chak, J. (2015). An investigation of positive and negative contact as predictors of intergroup attitudes in the United States, Hong Kong, and Thailand. Journal of Cross-Cultural Psychology, 46(3), 454-468. doi:10.1177/0022022115570313

Tetlock, P. E. (2002). Social functionalist frameworks for judgment and choice: Intuitive politicians, theologians, and prosecutors. Psychological Review, 109(3), 451-471. doi:10.1037/0033-295X.109.3.451

Tropp, L. R. (2008). The role of trust in intergroup contact: Its significance and implications for improving relations between groups. In U. Wagner, L. R. Tropp, G. Finchilescu, \& C. Tredoux (Eds.), Improving intergroup relations: Building on the legacy of Thomas F. Pettigrew (pp. 91-106). 
Turner, R. N., Hewstone, M., \& Voci, A. (2007). Reducing explicit and implicit outgroup prejudice via direct and extended contact: The mediating role of self-disclosure and intergroup anxiety. Journal of Personality and Social Psychology, 93(3), 369-388. doi:10.1037/0022-3514.93.3.369

Uenal, F. (2016). Disentangling islamophobia: The differential effects of symbolic, realistic, and terroristic threat perceptions as mediators between social dominance orientation and islamophobia. Journal of Social and Political Psychology, 4(1), 66-90. doi:10.5964/jspp.v4i1.463

Van de Vyver, Houston, D. M., Abrams, D., \& Vasiljevic, M. (2016). Boosting belligerence: How the July 7, 2005, London bombings affected liberals' moral foundations and prejudice. Psychological Science, 27(2), 169-177. doi:10.1177/0956797615615584

Vasilopoulos, P., Marcus, G. E., \& Foucault, M. (2017). Emotional responses to the Charlie Hebdo attacks: Addressing the authoritarianism puzzle. Political Psychology, doi:10.1111/pops.12439

Vedder, P., Wenink, E., \& van Geel, M. (2017). Intergroup contact and prejudice between Dutch majority and Muslim minority youth in the Netherlands. Cultural Diversity \& Ethnic Minority Psychology. doi:10.1037/cdp0000150

Vezzali, L., Capozza, D., Stathi, S., \& Giovannini, D. (2012). Increasing outgroup trust, reducing infrahumanization, and enhancing future contact intentions via imagined intergroup contact. Journal of Experimental Social Psychology, 48(1), 437-440. doi:10.1016/j.jesp.2011.09.008

Wakimoto, R. (2011). Reconstruction of the subjective temporal distance of past interpersonal 
experiences after mortality salience. Personality and Social Psychology Bulletin, 37(5), 687-700. doi:10.1177/0146167211400422

White, F. A., \& Abu-Rayya, H. (2012). A dual identity-electronic contact (DIEC) experiment promoting short- and long-term intergroup harmony. Journal of Experimental Social Psychology, 48(3), 597-608. doi:10.1016/j.jesp.2012.01.007

White, C., Duck, J. M., \& Newcombe, P. A. (2012). The impact of media reliance on the role of perceived threat in predicting tolerance of Muslim cultural practice. Journal of Applied Social Psychology, 42(12), 3051-3082. doi:10.1111/j.1559-1816.2012.00973.x

Whitehead, J. W., \& Aden, S. H. (2001). Forfeiting enduring freedom for homeland security: A constitutional analysis of the USA Patriot Act and the Justice Department's anti-terrorism initiatives. Am. UL Rev., 51, 1081.

Wilson, A. E., \& Ross, M. (2001). From chump to champ: People's appraisals of their earlier and present selves. Journal of Personality and Social Psychology: Attitudes and Social Cognition, 80(4), 572-584. doi:10.1037/0022-3514.80.4.572

Wright, S. C., Aron, A., McLaughlin-Volpe, T., \& Ropp, S. A. (1997). The extended contact effect: Knowledge of cross-group friendships and prejudice. Journal of Personality and Social Psychology, 73(1), 73-90. doi:10.1037/0022-3514.73.1.73 